DOI: $10.20472 / S S .2019 .8 .2 .008$

\title{
THE JOB ANALYSIS OF SCHOOL DIRECTORS IN CZECH REPUBLIC
}

\section{EVA URBANOVÁ}

\begin{abstract}
:
The aim of the paper is to compare selected work activities of the school directors in comparison of the results of the international survey Talis 2018 and to reflect these activities of the authors' survey results by students of the study program School Management at the Faculty of Education, Charles University in Prague. The goal of the paper is to define and discuss some part of job analyses of school directors by educational management students in terms of their theoretical knowledge, practical skills, management and human resources management development potential. From the perspective of future management of the students, authors' research results support the assumption that educational management students gained experience by this professional praxis in the time of study. The results show the agreement and differences between the results of the international survey and the reality in schools from the point of view of students who have completed these practices. Research question is What are the main work activities aimed at school management and how the opinions from the survey on them are different.
\end{abstract}

\section{Keywords:}

school director, job analysis, management, education, higher education, departmental school

JEL Classification: 120, J24, J29

\section{Authors:}

EVA URBANOVÁ, Charles University, Faculty of Education, Department of Andragogy and Educational Management, Czech Republic, Email: eva.urbanova@pedf.cuni.cz

\section{Citation:}

EVA URBANOVÁ (2019). The job analysis of school directors in Czech Republic. International Journal of Social Sciences, Vol. VIII(2), pp. 134-144., 10.20472/SS.2019.8.2.008 


\section{Introduction}

Unlike companies that often have different managers for each area (Chief Financial Officer, Chief Technical Officer, Production Manager, HR Director, Chief Operating Officer, etc.), the school director is often alone and has to deal with many unexpected situations. The school director performs functions as a teacher, employer, economist, lawyer, psychologist, human resources officer and is responsible for the smooth running of the school, which consists mainly in ensuring the teaching and education in terms of personnel and content. They must manage and lead people, communicate, decide on the use of funds, seek additional financial resources, evaluate and reward employees and, last but not least, carry out direct educational activities.

The director of each school, its development and the quality of its pupils' performance is the school director as the statutory representative of the organization. In Czech Republic the position of director of the school - primary and secondary school - is school director. In others countries in Europe there are using to name of position as director of school, headmaster or head teacher. It depends of responsibilities in this position. In Czech Republic the responsibilities of school director are ones of largest in this position in the world. Many school directors in Czech Republic are women, mainly lead primary and secondary schools. His/her role is often underestimated, although the consequences of his decision-making affect every day a wide range of educational and training activities and other activities, which he often did not even know at the time of the appointment decree.

The school director is not a typical representative of the teaching profession, especially in terms of the extent of direct teaching activity and the nature or structure of the work he holds in addition to his own teaching. They must be able to manage the school and take responsibility for developing school development strategies. The school director must be comprehensively educated in many areas with overlapping disciplines, be an expert in school management and quality management with the ability to reflect external influences on education.

Any legal regulation in the Czech Republic knows the concept of the school director's job, and therefore his work activities cannot be precisely defined. Due to the nature of the function of the school director, it is not possible to precisely specify all the work activities the school director carries out during the school year, nor can it be divided into precisely defined periods of time. He solves some problems by himself, others delegate, advises colleagues to the director, founder, but he is responsible for the final decision.

The prerequisites for the performance of the activities of the school director are set out in Czech Republic in Act No. 563/2004 Coll., On Educational Staff and on Amendments to Certain Acts, as amended. In addition to fulfilling the prerequisites for teaching staff (legal capacity, professional qualifications for direct teaching, integrity, medical fitness and knowledge of the Czech language), in accordance with Section 5 (2), the school may be established by the Ministry of Education, Youth and Sports, a region, municipality or voluntary association of municipalities whose tasks include tasks in the field of education, only those who, in addition to the prerequisites referred to in paragraph 1, have at least two years from the date on which they started to work as a school head for directors in the framework of further education of pedagogical staff pursuant to $\S 24$ par. and). Pursuant to Section 5 (3) of this Act, the obligation to study for a school director established by the Ministry, a region, a 
municipality and a union of municipalities does not apply to the scholl director who has acquired a degree in education management from an accredited program of school management or education. Lifelong learning by a school focused on the organization and management of education.

In theory of job description there is job analysis and job description that describe all the components of any work, including school management. In job description are analyses all part of job activities and responsibilities of each position as knowledge of activities on the job and personality type, announcement of admission - requirements, incorporation worker and adaptation, workers compensation as salary, wages, benefits; the development process as staff training, skills training, planning and implementation of career, motivation and stimulation and some parts of working environment. As main part in job description are:

- work task (goal and result of work),

- the extent of obligations,

- responsibility,

- content of the work - the number, type of tasks,

- autonomy work,

- place an individual in an organization,

- the organizational structure.

In the job description we usually describe main questions on job:

- Who performs the work, job title, job function?

- What work requires it, its nature, nature of the tasks, structure?

- What are permanent and regular duty in job function?

- What is main part of responsibility?

- How the work is done?

- Why are the tasks and duties performed as they are?

- When the tasks and duties perform?

- Where are performed-site, workplace?

- What is the relative position of the different tasks and responsibilities?

- Who is the person in charge?

- What is the relationship of the job to other jobs?

- What are performance standards?

- There is a possibility of training at work?

- What are the usual working conditions? (Koubek, 2015)

In Czech schools, staffing activities enable the director to provide enough capable and motivated staff to achieve the school's strategic goals. The school needs an optimal system of selecting, evaluating, remunerating and educating staff to perform the agreed work and achieve the desired performance. The basis of the personnel activities system is:

- Staff selection - the school provides competent and motivated staff to achieve the desired goals.

- Staff assessment - the school assesses the actual performance of staff for effective management, fair remuneration and continuous education.

- Remuneration of employees - the school fairly appreciates the real performance of employees and stimulates them to work more efficiently. 
- Education - the school consistently creates, deepens and expands the abilities (knowledge, skills, behavior) of employees to achieve the required performance. (Šikýř, Borovec, Lhotková, 2012)

In Czech schools are described maily competences/resp. part of job description of management staff in education who include the following areas:

- Leadership (strategic thinking) - creating and fulfilling the vision, setting priorities, presenting and promoting the school, motivating employees.

- Managerial (development of organization) - determination of strategy, personnel activities, provision of resources, running of the system.

- Professional (in terms of function) - knowledge of legal and economic regulations, knowledge of the school context, communication skills, language skills.

- Personality - time management, self-development, self-reflection, decision-making, work with stress.

- Social - team building, problem and conflict resolution, resistance management, cooperation with partners, acceptance of conditions.

- Management and evaluation of the educational process - curriculum planning and creation, process evaluation, implementation of new knowledge into the educational process, use of feedback for process improvement. (Lhotková, Trojan, Kitzberger, 2012)

The role of a school directors in Czech Republic is often underestimated, although the implications of his/her decision-making influence a wide range of educational activities on a daily basis. In the context of a rapidly evolving and changing society, there is demand for demonstrable use of learning outcomes in practice. There was great interest in educational leadership in the early 21 st century because of the widespread belief that the quality of leadership makes a significant difference to school and student outcomes (Lorencová, 2017).

In the Czech Republic as well as abroad, emphasis is on the professional preparation of school directors, their lifelong learning and the development and cultivation of their competences. (Šafránková, Šikýr̆, 2018). Schools are open systems, which is why they include much heavier duties for school managers; it can be concluded that school managers, the head teacher and his deputies have to cope with many different problems and even crises. (Dos, Sagir, Cetin, 2015). Considering that some university-based school director preparation programmes may not be properly training school directors for leadership roles, "grow your own" leadership development programmes have become more popular across the US (Tingle, Corrales, Peters, 2017).

The education of school directors and other senior staff in schools must necessarily reflect the ongoing changes in the education sector and society as a whole (Lapina, \& Stuken, 2018). The school directors must be comprehensively educated in many areas with sectoral overlaps, be an expert in school management, and manage the quality of teaching with the ability to reflect on external influences on education. However, since there is no obligation for prior systematic training in the field of school management, leadership, law or economics, the system has long been in the position of experienced and certified teachers who are, however, not ready for the school director's job. The image of a democratic school director with a participative leadership style is more effective, people work with pleasure, fulfil more tasks, are motivated to perform their work, they feel respected, appreciated and have high self-esteem, 
which can only benefit the school organization and the educational act (lurea, 2017, Bolam, 2014).

The quality of school directors is one of the key factors that significantly influence the quality of teaching and learning at all levels of the education system. It is important to optimize the training of school directors, resp. leaders and to identify the importance of each of the school director's job analysis profile items and the needs and requirements of management based on their day-to-day practice. School management leadership competence who is part of job description of this position is divided into four spheres - strategy development, pedagogical process management, school development and management as an institution, human resource management and development. Particular attention should be paid to vocational education and training to improve and develop appropriate key competences to characterize a good school director (Bitter, Hašková, \& Pisoňová, 2014).

\section{Goal and Method}

The aim of the paper is to compare selected work activities of the school directors in comparison of the results of Czech documents of Ministry of Education, Youth and Sports Czech Republic and the international survey Talis 2018 and to reflect these activities of the authors' survey results by students of the study program School Management at the Faculty of Education, Charles University in Prague. The goal of the paper is to define and discuss some part of job analyses of school directors by educational management students in terms of their theoretical knowledge, practical skills, management and human resources management development potential. From the perspective of future management of the students, authors' research results support the assumption that educational management students gained experience by this professional praxis in the time of study. The results show the agreement and differences between the results of the international survey and the reality in schools from the point of view of students who have completed these practices. Research question is "What are the main work activities aimed at school management and how the opinions from the survey on them are different?"

Methodology for analyses of professional practice is based on 30 semi structured interviews on students managerial practice reflection and results of five questions from quantitative research by using questionnaire with 15 questions with Likert scale, 15 open questions and 10 identification of respondents. The survey was realised at the end of the winter semester of the academic year of 2018/2019, a research survey was conducted among 90 students of the 1st - 2rd year of the School Management program $(47+43)$ aimed at evaluating managerial practices. After completing the practice in the given semester, the students completed their assessment focused on the content, organization and lecturing skills of the school director where the practice took place, and at the end they made a self-reflection.

\section{Results and Discussion}

The school director is a leading pedagogue whose work activities are diverse in practice and cover many areas (managerial, educational, psychological, legal, economic, human resources, etc.), which are governed in particular by the legal regulations he should be familiar with. The only measurable information in the school director is the performance of the direct teaching activity, ie the work of the teacher. The content of this work is defined in the catalogue of works (Government Regulation No. 222/2010 Coll., On the catalogue of works in 
public services and administration, as amended), according to which directors are assigned to the 12th or 13th grade.

Work activities of school director include:

- comprehensive educational and educational activities related to the creation and continuous updating of pedagogical documentation and individual educational plans,

- development of concepts for the development of fields of education,

- comprehensive educational activities in the system of further education of pedagogical staff associated with the creation of educational programs accredited in the system of further education of pedagogical staff and their evaluation,

- development of a concept for the development of school educational programs,

- specialized methodological activities in the field of pedagogy and psychology,

- creation and coordination of international projects focused on education and training.

The weekly scope of direct pedagogical activity in the Czech Republic is determined by the school director by Government Regulation No. 75/2005 Coll. from the number of classes, departments, study groups, courses, educational groups, or children, pupils or students at school. There is an inverse proportion, the more of them, the less direct pedagogical activities the school director performs.

Other work activities that are set by the Education Act include:

- making decisions on all matters relating to the provision of education and school services,

- responsibility for ensuring that schools and school facilities provide education and school services in accordance with the Education Act and educational programs,

- responsibility for the professional and educational level of education and school services,

- creation of conditions for the performance of inspection activities of the Czech School.

Inspectorate and adoption of subsequent measures,

- creating conditions for further education of pedagogical staff and for the work of the school board,

- ensuring that underage pupils and students and legal guardians of underage children and pupils are informed in a timely manner about the progress and outcomes of education of the child, pupil or student;

- ensuring co-operation in the implementation of the educational outcomes' programs announced by the Ministry of Education, Youth and Sports;

- responsibility for ensuring supervision of children and minors in school and school facilities.

Furthermore, the school director establishes the pedagogical council as its advisory body, discussing with it all essential pedagogical documents and measures concerning the school's 
educational activities. In its decision-making, the school director takes into account the opinions of the pedagogical board. The pedagogical council is formed by all pedagogical staff of the school.

The school director and school facility established by the state, region, municipality or association of municipalities determines the organization and conditions of operation of the school and school facility and is responsible for using state budget funds in accordance with the purpose for which they were allocated.

The director of the school and school facility of all founders decides on the rights and obligations in the area of the state administration in the cases specified in the Education Act.

The International Teaching and Learning Survey TALIS 2018 (Teaching and Learning International Survey) is an international survey that provides teachers and principals with the opportunity to contribute to the analysis of education and educational policy. It is conducted under the leadership of the Organization for Economic Cooperation and Development (OECD).

The TALIS survey focuses, among other things, on the management of schools, where it determines the representation of other persons in the school management who are involved in its management or development. Is part of them:

- Deputy Director,

- Chief Economist,

- Representatives for the education of a particular field (eg for certain subjects or levels of education),

- Teachers,

- School board,

- Legal guardians,

- Pupils.

Furthermore, TALIS examines the work activities of school directors, including:

- appointing or hiring teachers,

- temporary or permanent dismissal of teachers from employment,

- determining the starting salaries of teachers, including the salary assessment,

- deciding to increase teachers' salaries,

- deciding on the use of funds from the budget within the school,

- establishing principles for assessing pupil behaviour and disciplinary measures,

- establishing principles for pupil assessment, including national or regional assessment,

- deciding on the admission of pupils to school,

- choice of teaching materials,

- determining the content of a subject or seminar, including school education programs and framework education programs,

- deciding on the offer of courses and seminars.

When comparing the work activities of the school director determined by the legislation of the Czech Republic and the content of the questionnaire in the framework of the international survey TALIS 2018, it is clear that it is possible to compare internationally and even the school 
year. The main indicator is the size of the school, because the smaller the school, the fewer people involved in the management of the school and often the director is at his own discretion.

The monitored work activities with the time devoted to it include:

- administrative tasks and meetings,

- school management activities and meetings,

- activities and consultations aimed at the school curriculum and teaching,

- dealing with pupils,

- dealing with legal representatives,

- dealing with a local community of people or representatives of business or industry from the community.

The results of the international survey TALIS 2018 are not yet known, however, at the end of the winter semester of the academic year 2018/2019 the authors conducted a research survey of 90 students of the 1 st and 2 nd year $(47+43)$ of the study program management practices, which students must complete during each semester at schools cooperating with the department (the so-called departmental schools). In the given semester, the practice focused on analysing the work activities of the school director that the students met in managerial practice. The survey took the form of 30 semi-structured interviews and a questionnaire survey with 15 open questions and 5 for the identification of respondents.

On the basis of the research it was found out that practical preparation of students of the School Management study program in the form of managerial practices at departmental schools is a beneficial and important part of the study. Students' knowledge gained in the winter semester of the academic year 2018/2019 in the practical part of the study reflects its theoretical part, and departmental schools allow students to become acquainted with selected activities of the school director in an authentic school environment.

Table 1 Students opinions on school director responsibilities - Obtained results of practice evaluation by students:

\begin{tabular}{|l|}
\hline Students opinions \\
\hline creation of strategic documents \\
\hline educational and educational activities \\
\hline recruiting and motivating employees to implement strategies \\
\hline prioritization \\
\hline solving tasks according to the current situation and importance \\
\hline preparation for educational meetings \\
\hline distribution of tasks and deadlines \\
\hline setting the school budget \\
\hline set up how information and documents are shared with other colleagues \\
\hline representing the school in negotiations with legal guardians, social partners, founder, \\
authorities, etc. \\
\hline delegating work to other employees \\
\hline ensuring the operation of the school from an economic point of view \\
\hline ensuring sufficient qualified teaching staff \\
\hline ensuring the adaptation of new employees (creation of a manual) \\
\hline
\end{tabular}




\begin{tabular}{|l|}
\hline appointment of deputy directors and other authorized persons \\
\hline quality control of work (observation) and observance of work obligations \\
\hline responsibility for the implementation of educational programs \\
\hline review of pedagogical documentation \\
\hline $\begin{array}{l}\text { searching for financial resources beyond the state budget and the budget set by the founder } \\
\text { (grants, projects, sponsorship) }\end{array}$ \\
\hline ensuring the publicity of the school \\
\hline communication with legal representatives, employees, social partners, founder \\
\hline leadership \\
\hline studying legislation \\
\hline operative solution of the problem \\
\hline creation of a system of evaluation and remuneration of employees \\
\hline setting up a training plan for each employee (career development plan) \\
\hline keeping school documentation \\
\hline decision-making in the admission procedure \\
\hline
\end{tabular}

\section{Source: Author results}

The research survey among students showed that due to many duties, which are not even defined in the scope of work, directors are burdened to such a degree that they often do not have time for compulsory direct pedagogical activity which they have as one of their work activities given by legislation to represent colleagues. The worst situation is in small schools where there is no one to whom to delegate selected work activities.

\section{Conclusion}

Unlike companies that often have a different manager for each area of their activity, the school director is often alone and has to deal with many unexpected situations. The school director performs functions as a teacher, employer, economist, lawyer, psychologist, human resources officer and is responsible for the smooth running of the school, which consists mainly in ensuring the teaching and education in terms of personnel and content. They must manage and lead people, communicate, decide on the use of funds, seek additional financial resources, evaluate and reward employees and, last but not least, carry out direct educational activities.

In accordance with legal regulations, the school director performs the following work activities:

- direct teaching activities,

- comprehensive educational and educational activities,

- creation of concepts,

- comprehensive educational activities in the system of further education of pedagogical staff,

- development of a concept for the development of school educational programs,

- making decisions on all matters relating to the provision of education and school services,

- responsibility for the use of state budget funds.

In addition, the following activities of the school director are monitored in the Czech Republic in the framework of international surveys: 
- recruitment / dismissal of teachers,

- salaries for teachers,

- deciding on the use of funds from the budget within the school,

- establishing principles for assessing pupils,

- deciding on the admission of pupils to school,

- choice of teaching materials,

- determining the content of a subject or seminar, including school educational programs and framework educational programs.

In the research of the author, the students of the School Management study program tend to work that is mainly related to ensuring the proper operation of the school.

- educational and educational activities,

- ensuring sufficient qualified teaching staff,

- ensuring the school's economic operation (budget),

- seeking additional financial resources beyond the budget (grants, projects, sponsorship),

- ensuring the capacity of the school,

- ensuring the publicity of the school,

- delegating work activities to other employees, if possible,

- solving tasks according to the current situation and importance,

- representing the school in negotiations with legal guardians, social partners, founder, authorities, etc.,

- quality control of work (observation) and observance of work duties.

Of course, the school director can delegate selected work activities to other staff, but he will always be responsible. In small schools, however, there is often no one to delegate to. Unfortunately, the high level of school autonomy in the Czech Republic is often a problem for school directors, because in practice there are often conflicts with legal regulations that do not correspond to the real situation in education. On the other hand, the school director is often affected by the school director to a high degree of competence. One of the students' knowledge of managerial practices tied to the number of female directors in primary education in the Czech Republic was that they do not recommend that women with young children exercise managerial positions, function manageable.

For further research, the author will focus on monitoring the work activities of school directors in the Czech Republic.

\section{References}

BITTEROVÁ, M., HAŠKOVÁ, A. and PISOŇOVÁ, M. (2014). School Leader's Competencies in Management Area. Procedia - Social and Behavioral Sciences [online]. 149, 114-118 [cit. 201908-08]. DOI: 10.1016/j.sbspro.2014.08.170. ISSN 18770428. Available from: https://linkinghub.elsevier.com/retrieve/pii/S1877042814048460

BOLAM, R. (2014). Educational Administration, Leadership and Management: Towards a Research Agenda. Educational Management: Redefining Theory, Policy and Practice, 192-205. doi:10.4135/9781446219676.n15 
DOS, I, SAGIR, M. and CETIN, R. B. (2015). Classsifying Daily Problems of School Managers. Procedia - Social and Behavioral Sciences [online]. 197, 2040-2045 [cit. 2019-08-08]. DOI: 10.1016/j.sbspro.2015.07.568. ISSN 18770428. Available from: https://linkinghub.elsevier.com/retrieve/pii/S1877042815045875

IUREA, C. (2017). The Role of the Manager in the Succes of School Organizations [online]. In: 2017-524, p. 188-193 [cit. 2019-08-08]. DOI: 10.15405/epsbs.2017.05.02.25. Available from: http://www. futureacademy.org.uk/files/images/upload/25.\%20EduWorldF\%202017.pdf

KOUBEK, J. (2015). Human resources management: basics of modern human resources management (Řizení lidských zdrojů: základy moderní personalistiky). 5th edition. Praha: Management Press. ISBN 978-80-7261-288-8.

LAPINA, T. and STUKEN,T. (2018). Socio-professional characteristics of European managers: similarities and differences. In: The 12th International Days of Statistics and Economics. Conference Proceedings. September 6-8. Prague, Czech Republic. Edited by: Tomáš Löster, Tomáš Pavelka Published by Libuše Macáková, MELANDRIUM, Fügnerova 691,Slaný. pp.1038 1047. ISBN 978-80-87990-14-8

LHOTKOVÁ, I, TROJAN, V. and KITZBERGER, J. (2012). Competence of managers in education (Kompetence rídících pracovníků ve školství). Praha: Wolters Kluwer Česká republika. ISBN 97880-7357-899-2.

LORENZOVA, J. (2017). CHILDHOOD THROUGH THE LENS OF SOCIAL PEDAGOGY. International Journal of Social Sciences [online]. VI(1) [cit. 2019-08-28]. DOI: 10.20472/SS2017.6.1.005. ISSN 1804980X. Available from: http://iises.net/international-journal-of-social-sciences/publicationdetail-945

ŠAFRÁNKOVÁ, J. M. and ŠIKÝŘ, M. (2018). Responsibilities and competencies in personnel management at Czech schools. Oeconomia Copernicana [online]. 2018, 9(3), 529 -543 [cit. 201908-08]. DOI: 10.24136/oc.2018.027. ISSN 2353-1827. Available from: http://economicresearch.pl/Journals/index.php/oc/article/view/1054

ŠIKÝŘ, M., BOROVEC, D. and TROJANOVÁ, I. (2016). Personalistika v řízení školy. 2nd edition. Praha: Wolters Kluwer. ISBN 978-80-7552-264-1.

TINGLE, E., CORRALES, A. and PETERS, M. L. (2017). Leadership development programs: investing in school principals. Educational Studies [online]. 1-16 [cit. 2019-08-08]. DOI: 10.1080/03055698.2017.1382332. ISSN 0305-5698. Available from: https://www.tandfonline.com/doi/full/10.1080/03055698.2017.1382332

\section{Acknowledgment}

This paper was supported by Charles University PROGRES Q17 - Teacher training and teaching profession in the context of science and research. 